\title{
Exterior and interior indicators of development of Tsigai breed young sheep on the background of diet supplement with iodine in liposomal form
}

\author{
Aleksandra Pashtetskaia ${ }^{1,{ }^{*}}$, Vladimir Pashtetskiy ${ }^{1}$, Pavel Ostapchuk ${ }^{1}$, and Sergey \\ Yemelianov $^{1}$ \\ ${ }^{1}$ Federal State Budget Scientific Institution "Research Institute of Agriculture of Crimea", 295493, \\ Simferopol, Crimea, Russia
}

\begin{abstract}
The effect of the liposomal form of antioxidants with the inclusion of organic iodine on the growth of young Tsigai sheep was described in the article. The liposomal form allowed increasing average daily gain of young animals by $11.9 \%$ and live weight by $10.8 \%$ compared to the control one-year age group. The animals of the experimental group were characterized by more embodied meat forms according to the analysis of their exterior. Interior indicators were represented by the increased content of RBC that reached $1.8 \times 10^{12}$ cells per liter or $25.7 \%(\mathrm{p} \leq 0.001)$, and $\mathrm{WBC}-1.80 \times 10^{9}$ cells per liter or 20.0 $\%(\mathrm{p} \leq 0.01)$ at 7 -months age; $1.9 \times 10^{12}$ cells per liter $(\mathrm{p} \leq 0.001)$ and $1.74 \times 10^{9}$ cells per liter $(\mathrm{p} \leq 0.05)$ at 12 months, respectively. This fact was due to the increased content of monocytes and neutrophils: the difference between the control and experimental groups of animals was within $1.1 \%$ and $0.6 \%$ at the age of 12 months.
\end{abstract}

\section{Introduction}

Growing sheep and creating optimal conditions for feeding and keeping them is important because of the lack of natural pasture and moisture [1]. Feeding conditions affect the growth efficiency of young sheep [2].

Feed additives are the catalysts for important processes in the animal's body. They have some positive effect on the quality of feed, animal health, and productivity due to various antioxidant factors included in the composition. They can be classified as feed additives that affect the external properties, toxin inhibitors, and various zootechnical additives, such as growth stimulants, minerals, vitamins, enzymes, antibiotics, etc. [3].

The problem of the delivery of vital substances is relevant since antioxidants often carry a hydrophobic characteristic. Liposomes are used for this purpose. The antioxidant is placed inside the liposomes, which are nanospheres of phospholipids. Tests show what these phospholipids are mostly harmless [4].

Stress factors affect the metabolic activity of a number of internal systems of the body and the productivity of animals [5]. These factors cause the so-called "oxidative stress",

* Corresponding author: pashtetskaia@gmail.com 
which occurs when excessive production of free radicals counteracts antioxidant mechanisms [6,7]. The suppression of the effects of oxidative stress occurs when antioxidants are added to the diet of sheep [8].

Due to the fact that the liposomal form of antioxidants improves the availability of vital substances, the main goal of our research was to study the effect of the liposomal form of antioxidants with the inclusion of organic iodine on the growth and development of young Tsigai sheep. The choice of this valuable element is dictated by its deficiency in the biosphere of the Crimea [9-13]. Enriching the diet of animals with iodine will improve the physiological state of animals [14].

\section{Materials and methods}

The studies were conducted in 2018-2019. Young sheep of the Tsigai breed born in 2018 served as the material for the research. Animals of the control group received the main diet (MD). It consisted of 1) from the $10^{\text {th }}$-day - concentrated feed; 2) in the suckling period mixed feed, which included one feed unit and 120-125 g of digestible protein; 3) after weaning (4.5 months) - 1.36 energy feed units at 6-8 months; 1.49 - at $8-10$ months; $1.64-$ at 10-12 months. Furthermore, the dietary ensure of the metabolic energy in these periods was $13.65,14.91$ and $16.38 \mathrm{MJ}$, respectively. Animals of the experimental group received MD + feed supplemented with organic iodine, omega-3 polyunsaturated fatty acids and beta-carotene (FS). FS was added in the period from 4.5 months up to 12 months in the amount of 5 grams per head per day. The construction of the dynamics of the external profile was calculated on the basis of body measurements. We studied such interior features of young sheep as red blood cells (RBC), white blood cells (WBC), and differential leukocytes count (DLC). The correlation coefficients of the studied characteristics were calculated.

\section{Results}

The dynamics of the indicators of live weight of young animals in the period of ontogenesis is one of the important indicators in sheep breeding. Therefore, table 1 shows the dynamics of live weight of young sheep in the experiment from birth to 12 months, and table 2 shows the features of the development of young animals in this period to study the influence of the liposomal form of antioxidants

Table 1. Dynamics of live weight of young sheep in the experiment during the period from birth to 12 months, kg. $\mathrm{n}=10\left(^{\frac{\bar{X} \pm S_{\bar{X}}}{C_{v}}}\right)$

\begin{tabular}{|c|c|c|c|c|}
\hline Group & Birth & Weaning & 7 months & 12 months \\
\hline \multirow{2}{*}{ Control } & $3.7 \pm 0.05$ & $26.1 \pm 0.78$ & $42.3 \pm 0.60$ & $55.4 \pm 0.86$ \\
\cline { 2 - 5 } & 4.4 & 9.5 & 4.5 & 4.9 \\
\hline \multirow{3}{*}{ Experimental } & $3.5 \pm 0.10$ & $26.6 \pm 0.40$ & $\begin{array}{c}46.8 \pm \\
0.77^{* * *}\end{array}$ & $\begin{array}{c}61.4 \pm \\
0.82^{* * *}\end{array}$ \\
\cline { 2 - 5 } & 6.8 & 7.8 & 5.2 & 4.2 \\
\hline
\end{tabular}

Note: in this and the following tables: three confidence limits were accepted for data analysis: * - at $p \leq 0.05 ; * *$ - at $p \leq 0.01 ; * * *$ - at $p \leq 0.001$

The live weight of young animals from the experimental group at 7 months is higher than that of the control one by $4.5 \mathrm{~kg}$ or $10.6 \%(\mathrm{p} \leq 0.001)$. A similar trend remained at the age of 12 months (by $6.0 \mathrm{~kg}$ or $10.8 \%(\mathrm{p} \leq 0.001))$. 
Table 2. Dynamics of average daily increments of young sheep in the experiment during the period from birth to 12 months, $\mathrm{n}=10\left(\frac{\bar{X} \pm S_{\bar{X}}}{C_{v}}\right)$

\begin{tabular}{|c|c|c|c|c|}
\hline \multirow{3}{*}{ Group } & \multicolumn{4}{|c|}{ The period of ontogenesis of the young sheep: } \\
\cline { 2 - 5 } & $\begin{array}{c}\text { from birth to } \\
\text { weaning }\end{array}$ & $\begin{array}{c}\text { from weaning } \\
\text { to 7 months }\end{array}$ & $\begin{array}{c}\text { from 7 to 12 } \\
\text { months }\end{array}$ & $\begin{array}{c}\text { from birth to } \\
\text { 12 months }\end{array}$ \\
\hline \multirow{2}{*}{ Control } & $149.7 \pm 5.27$ & $180.0 \pm 7.73$ & $145.6 \pm 5.34$ & $141.8 \pm 2.24$ \\
\cline { 2 - 5 } & 11.1 & 13.6 & 11.6 & 5.0 \\
\hline \multirow{2}{*}{ Experimental } & $154.2 \pm 2.57$ & $224.4 \pm 5.22 * *$ & $162.2 \pm 4.22 *$ & $158.7 \pm 1.33^{* *}$ \\
\cline { 2 - 5 } & 8.7 & 12.1 & 8.2 & 4.4 \\
\hline
\end{tabular}

Dynamics of average daily increments of young sheep in the experiment during the period from birth to 12 months stated in table 2 . Weight gain in the period before weaning slightly varies between groups and ranges from 149.7 to $154.2 \mathrm{~g}$ (table 2).

The increase in average daily growth in the period from weaning to 7 months at the experimental group is higher by $44.4 \mathrm{~g}$ or $24.7 \%$ ( $\mathrm{p} \leq 0.01)$.

Reliable advantages of young animals of the experimental group in the period from 7 months to the age of 1 year are preserved compared to sheep of the control group; the average daily increase is $16.7 \mathrm{~g}$ or $11.5 \%(\mathrm{p} \leq 0.05)$.

Analyzing the data of the average daily increase from birth to 12 months, an excess of $16.9 \mathrm{~g}$ or $11.9 \%$ was obtained $(\mathrm{p} \leq 0.01)$.

Thus, FS feeding has a positive effect on the average daily increase.

The correlation of indicators of the development of the live weight of young sheep in the control group was analysed.

The positive influence of the live weight at the age of 20 days on the weight at weaning $(\mathrm{r}=0.91)(\mathrm{p} \leq 0.001)$ and indicators of development in the period before weaning was noted. Absolute $(\mathrm{r}=0.87) \quad(\mathrm{p} \leq 0.001)$ and average daily $(\mathrm{r}=0.87) \quad(\mathrm{p} \leq 0.001) \quad$ increases were identified.

There was a positive correlation between the absolute and average daily increments in all the studied periods $(\mathrm{r}=0.98)(\mathrm{p} \leq 0.001)$.

The live weight of young animals at 20-day age is positively and reliably associated with the live weight both at 7 months $(r=0.60)(\mathrm{p} \leq 0.01)$ and one year( $\mathrm{r}=0.74)(\mathrm{p} \leq 0.01)$. During the period of early ontogenesis (from birth to weaning), development indicators are positively associated with those at the age of 12 months and vary from $0.52(\mathrm{p} \leq 0.01)$ to $0.82(\mathrm{p} \leq 0.001)$.

The correlation of the development factors of young sheep in the experimental group was studied. Patterns of development from birth to weaning at the experimental group are similar to those in the control group. Indicators of early ontogenesis are strongly associated with indicators of live weight at 12 months, which range from $0.59(\mathrm{p} \leq 0.01)$ to 0.88 $(\mathrm{p} \leq 0.001)$.

Thus, a positive and highly reliable relationship was established between the indicators of the initial stages of ontogenesis and the live mass at 12 months. The correlation degree increases from $0.53(\mathrm{p} \leq 0.05)$ to $0.61(\mathrm{p} \leq 0.01)$ in terms of the effect of the absolute increase before weaning on the live mass at 12 months and from $0.82(p \leq 0.01)$ to $0.88(p \leq 0.001)$, the live mass at 7 months affects the live mass at 12 months.

Thus, there was a positive and reliable relationship between the live weight at the age of 20 days (this feature is indirect in determining the milk content of the ewes) and the live weight of young animals at the age of one year. This indicates the importance of maternal influence on the growing body of the offspring. 
A number of researchers have proved that high milkiness of ewes (the milkiness is the live weight of a lamb at the age of 20 days multiplied by the coefficient of ewe' milk production) has a positive relationship with increased viability of lambs in later periods of ontogenesis [15].

The importance of evaluating body measurements during young sheep growing is dictated by the necessity to monitor the formation of the animal's body type. Table 3 shows the dynamics of body measurements of rams at 7 and 12 months in the experiment of feeding the feed additive.

At the age of 7 months, there was a significant difference $(p \leq 0.05)$ in the width of the chest, oblique length of the trunk, chest girth behind the shoulder blades and pastern girth at 2.8 (difference $17.3 \%), 1.6(2.9 \%), 2.8(4.2 \%)$ and $0.6(9.8 \%) \mathrm{cm}$, respectively.

At the age of 12 months, a significant difference is observed for all performance measurements in the experimental group compared to the same in the control one: height at the withers $-1.6 \mathrm{~cm}$ or $2.7 \%(\mathrm{p} \leq 0.05)$; height at the rump $-2.0 \mathrm{~cm}$ or $3.2 \%(\mathrm{p} \leq 0.01)$; depth of the chest $-0.6 \mathrm{~cm}$ or $2.3 \%(\mathrm{p} \leq 0.05)$; chest width $-3.8 \mathrm{~cm}$ or $18.8 \%(\mathrm{p} \leq 0,001)$; body length $-4.8 \mathrm{~cm}$ or $5.9 \%(\mathrm{p} \leq 0,01)$; chest girth behind the shoulders $-0.4 \mathrm{~cm}$ or $4.9 \%$ $(\mathrm{p} \leq 0.001)$; metacarpus $-0.4 \mathrm{~cm}$ or $4.9 \%(\mathrm{p} \leq 0.001)$.

Table 3. Body measurements of rams aged 7 and 12 months in the experiment with FS feeding, $n=5$

\begin{tabular}{|c|c|c|c|c|c|c|c|c|}
\hline \multirow[b]{2}{*}{ 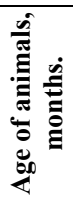 } & \multirow[b]{2}{*}{ 气̆ } & \multicolumn{7}{|c|}{ Measurements, cm } \\
\hline & & $\begin{array}{c}\text { Height } \\
\text { at } \\
\text { withers }\end{array}$ & $\begin{array}{c}\text { Height in } \\
\text { the } \\
\text { sacrum }\end{array}$ & $\begin{array}{c}\text { Depth of } \\
\text { chest }\end{array}$ & $\begin{array}{l}\text { Chest } \\
\text { width }\end{array}$ & $\begin{array}{l}\text { Body } \\
\text { length }\end{array}$ & $\begin{array}{c}\text { Chest } \\
\text { girth } \\
\text { behind the } \\
\text { shoulder } \\
\text { blades }\end{array}$ & $\begin{array}{l}\text { Pastern } \\
\text { girth }\end{array}$ \\
\hline \multirow{2}{*}{7} & Control & $\begin{array}{c}48.4 \pm \\
0.6\end{array}$ & $45.4 \pm 1.0$ & $\begin{array}{c}22.4 \pm \\
0.4 \\
\end{array}$ & $\begin{array}{c}16.2 \pm \\
0.8 \\
\end{array}$ & $\begin{array}{c}55.2 \pm \\
0.5 \\
\end{array}$ & $66.6 \pm 1.1$ & $6.1 \pm 0.2$ \\
\hline & $\begin{array}{l}\text { Experi- } \\
\text { mental }\end{array}$ & $\begin{array}{c}49,8 \pm \\
0.5\end{array}$ & $47,8 \pm 0.6$ & $\begin{array}{c}23,0 \pm \\
0.2\end{array}$ & $\begin{array}{c}19,0 \pm \\
0.2^{*}\end{array}$ & $\begin{array}{c}56,8 \pm \\
0.5^{*}\end{array}$ & $\begin{array}{c}69,4 \pm \\
0.5^{*}\end{array}$ & $\begin{array}{l}6,7 \pm \\
0.2 *\end{array}$ \\
\hline \multirow{2}{*}{12} & Control & $\begin{array}{c}60.4 \pm \\
0.7\end{array}$ & $62.6 \pm 0.7$ & $\begin{array}{c}26.4 \pm \\
0.6\end{array}$ & $\begin{array}{c}20.2 \pm \\
0.8\end{array}$ & $\begin{array}{c}63.8 \pm \\
0.8\end{array}$ & $81.4 \pm 1.4$ & $8.2 \pm 0.3$ \\
\hline & $\begin{array}{l}\text { Experi- } \\
\text { mental }\end{array}$ & $\begin{array}{c}62.0 \pm \\
0.9^{*}\end{array}$ & $\begin{array}{l}64.6 \pm \\
0.6^{* * *}\end{array}$ & $\begin{array}{c}27.0 \pm \\
0.5^{*}\end{array}$ & $\begin{array}{l}24.0 \pm \\
0.5 * * *\end{array}$ & $\begin{array}{c}65.8 \pm \\
1.0 * * *\end{array}$ & $\begin{array}{l}86.2 \pm \\
1.5^{* * *}\end{array}$ & $\begin{array}{c}8.6 \pm \\
0.2^{* * *}\end{array}$ \\
\hline
\end{tabular}

Body height and breast depth of animals of the control group at the age of 7 months positively correlates with measurements of height in the sacrum and indicators of breast development $(0.73(\mathrm{p} \leq 0.05)$ to 0.97 ( $\mathrm{p} \leq 0.05)$, respectively). The same measurements, at the age of 7 months, also have a positive impact on the development of body height, depth and width of the chest and trunk length at the age of 12 months $(0.68(\mathrm{p} \leq 0.05)$ to $0.89(\mathrm{p} \leq 0.05)$ units). Almost all indicators of body measurements at the age of 12 months are interconnected in a positive and highly reliable degree (from $0.75(\mathrm{p} \leq 0.01)$ to 0.97 $(\mathrm{p} \leq 0.001)$ units $)$.

The relationship between body measurements of young animals of the experimental group at 7 months showed a positive and reliable relationship between almost all measurements. At the age of 12 months, height at the withers positively correlates with height in the sacrum $(\mathrm{r}=0.91)(\mathrm{p} \leq 0.001)$, breast depth $(\mathrm{r}=0.82)(\mathrm{p} \leq 0.001)$, chest girth behind the shoulder blades $(r=0.99)(\mathrm{p} \leq 0.001)$ and pastern girth $(\mathrm{r}=0.84)(\mathrm{p} \leq 0.01)$. The height in the sacrum positively correlated with the chest girth behind the shoulder blades $(\mathrm{r}=0.91)$ $(\mathrm{p} \leq 0.001)$ and the pastern girth $(\mathrm{r}=0.74)(\mathrm{p} \leq 0.01)$. The same measurements positively correlated with the chest depth: $0.87(\mathrm{p} \leq 0.01)$ and $0.92(\mathrm{p} \leq 0.001)$ units, respectively. A positive relationship is observed between the width of the chest and the length of the body $(\mathrm{r}=0.74)(\mathrm{p} \leq 0.01)$ and the girth of the metacarpal bone $(\mathrm{r}=0.89)(\mathrm{p} \leq 0.001)$. 
Since body changes occur in the process of growth, it is possible to predict the productive characteristics of sheep by the indicators of the exterior. The exterior profile clearly shows the difference between the studied groups of animals.

Exterior at the age of 7 and 12 months showed that the indicators of the development of the skeleton, chest and massiveness of the body of young sheep from the experimental group were more intense.

Table 4 shows the dynamics of the content of the main blood cells in young sheep during the experiment.

Table 4. Dynamics of the content of blood cells of young sheep of the Tsigai breed in the experiment, $\mathrm{n}=3$

\begin{tabular}{|c|c|c|c|c|}
\hline \multirow{2}{*}{$\begin{array}{c}\text { Age, } \\
\text { month }\end{array}$} & RBC & WBC & RBC & WBC \\
\cline { 2 - 5 } & \multicolumn{2}{|c|}{ Control group } & \multicolumn{2}{c|}{ Experimental group } \\
\hline 5 & $6.80 \pm 0.47$ & $8.80 \pm 0.32$ & $7.20 \pm 0.47$ & $9.40 \pm 0.50$ \\
\hline 7 & $7.00 \pm 0.18$ & $9.00 \pm 0.36$ & $8.80 \pm 0.29^{* * *}$ & $10.80 \pm 0.47^{* *}$ \\
\hline 12 & $7.10 \pm 0.16$ & $9.16 \pm 0.30$ & $9.00 \pm 0.18^{* * *}$ & $10.90 \pm 0.50^{*}$ \\
\hline
\end{tabular}

When taking blood at the age of five months, the content of RBC varies from 6.8 to $7.2 \times 10^{12}$ cells per litre, and WBC - from 8.8 to $9.4 \times 10^{9}$ cells per litre.

At the age of 7 months, the content of RBC in young animals of the experimental group increased by $1.8 \times 10^{12}$ cells per litre or $25.7 \%(\mathrm{p} \leq 0.001)$, WBC - by $1.80 \times 10^{9}$ cells per litre or $20.0 \%(\mathrm{p} \leq 0.01)$. A similar feature persisted at the age of 12 months: the difference in the content of RBC was $1.9 \times 10^{12}$ cells per litre or $26.8 \%(\mathrm{p} \leq 0.001)$, WBC $-1.74 \times 10^{9}$ cells per litre or $19.0 \%(\mathrm{p} \leq 0.05)$.

The level of RBC and WBC in young animals in the experiment was within the normal range. However, this indicator was significantly higher in the experimental group.

DLC of young animals at the age of 12 months was studied. An increase of WBC was noted due to leukocytes (difference compared to control one was $0.9 \%$ ), monocytes (difference $-1.1 \%$ ) and neutrophils (difference $-0.6 \%$ ).

\section{Conclusions}

The influence of the liposomal form of antioxidants with the inclusion of organic iodine on the growth and development of young Tsigai sheep allowed improving the average daily increase by $11.9 \%$, live weight - by $10.8 \%$ compared to control. Animals of the experimental group are characterized by a greater extent of meat forms.

Interior indicators are due to the increased content of RBC (up to $1.8 \times 10^{12}$ cells per litre or $25.7 \%(\mathrm{p} \leq 0.001)$ ), and WBC (up to $1.80 \times 10^{9}$ cells per litre or $20.0 \%(\mathrm{p} \leq 0.01)$ ) at 7 months, and up to $1.9 \times 10^{12}$ cells per litre $(\mathrm{p} \leq 0.001)$, and $1.74 \times 10^{9}$ cells per litre $(\mathrm{p} \leq 0.05)$ at 12 months, respectively. This is possible because WBC content increases due to leukocytes at $0.9 \%$, monocytes at $1.1 \%$ and neutrophils at $0.6 \%$.

\section{References}

1. H. Hajji, S. Smeti, Ben Hamouda M., N. Atti, Animal Production Science, 56, 21152121 (2015) doi : https://doi.org/10.1071/AN14917

2. I. Ismailov, N. Tregubova, R. Kochkarov, A. Morgunova, N. Drizhd, Proceedings of the 8th International Scientific Conference Rural Development, 289 - 294 (2017) doi : http://doi.org/10.15544/RD.2017.125 
3. K. Karásková, P. Suchý, E. Straková, Czech J. Anim. Sci., 60, 521-530 (2015) doi: https://doi.org/10.17221/8594-CJAS

4. Z. E. Suntres, Journal of Toxicology, 2011, 16 (2011)

5. P. Celi, A. Di. Trana, Claps S. Vet. J., 184, 95-99 (2010)

6. K. K. Anand, V. Kumar, T. Kumar, R. Srivastava, The International Journal Of Science \& Technoledge, 3(7), 155-162 (2015)

7. G. Pizzino, N. Irrera, M. Cucinotta, G. Pallio, F. Mannino, V. Arcoraci, F. Squadrito, D. Altavilla, A. Bitto, Oxidative Medicine and Cellular Longevity, 13 (2017) doi :https://doi.org/10.1155/2017/8416763

8. M. F. Nawito, Amal R. Abd El Hameed, A. S. A. Sosa and Karima Gh. M. Mahmoud, Veterinary World, 9(8), 801-805 (2016) doi: 10.14202/vetworld.2016.801-805

9. L. A. Kutuzova, A. M. Lebedeva, L. J. Uzbekova, International student scientific Bulletin, 6, 25 (2018) URL : https://eduherald.ru/ru/article/view?id=19302 (Last accessed 12.07.2020)

10. A. V. Mikheeva, M. Yu. Dyakov, A. V. Krikova, Vestnik of SSMA, 17(4), 11-16 (2018)

11. S. C. Bath, M. P. Rayman, Lancet Diabetes Endocrinol, 6(2), 89-90 (2018) doi: http://doi.org/10.1016/S2213-8587(17)30133-X.

12. E. A. Pretell, E. N. Pearce, S. A. Moreno, Lancet Diabetes Endocrinol, 5(6), 412-414 (2017) doi: http://doi.org/10.1016/S2213-8587(17)30034-7.

13. H. G. Kekina, N. A. Golubkina, O. V. Tulchinskaya, Problems of nutrition, 83(5), 5157 (2014)

14. V. I. Alferova, S. V. Mustafina, O. D. Rymar, Clinical and experimental thyroidology, 15(2) (2019) doi: 10.14341/ket10353.

15. C. Burgos-González, M. Huerta-Aparicio, V. Aguirre, M. Pedernera, Trop Anim Health Prod, 50, 683 -687 (2018) doi: 10.1007/s11250-017-1448-8 